https://doi.org/10.48009/2_iis_2007_1-6

\title{
DEVELOPING A MARKETING STRATEGY TO INCREASE ENROLLMENT
}

\author{
Corrine M. Brown, Ohio University, brownc@ohio.edu
}

\begin{abstract}
Many factors have contributed to the downward spiral of IS enrollment. Many educators accept the downturn as the result of outside influences over which they have no control. When successful businesses experience a downturn, major intervention strategies are set in place so the business can adapt and succeed in an ever changing marketplace. This paper discusses a marketing strategy put in place to increase enrollment and interest in the MIS major. The background behind the development of each segment of the plan is outlined so that it can be replicated by other IS departments. The results show an increase in enrollment and student satisfaction with the MIS major.
\end{abstract}

Keywords: Marketing IT, Promoting IT, Career Choice, Academic Choice, Information Systems, Enrollment

\section{INTRODUCTION}

Bachelor's degree enrollment for business information systems programs on Ohio's thirteen public university main campuses peaked in 2003 with 1080 students enrolled. Two years later, Ohio's thirteen public universities reported 531 students enrolled in the same programs, a fifty percent decline. [8]

Between 1991 and 1993, IBM experienced a fifty percent decline in its primary product line, mainframe computer sales [15]. IBM's failures were not "simply the reflection of a changing marketplace" [15, pg 2] and neither is the drop in enrollment. Like many universities, "Big Blue was burdened with a vast, redundant bureaucracy that virtually guaranteed lifetime employment and resisted change with all its might” [15, pg 2]. The problems facing universities are not that different from those at IBM or any other large bureaucracy. When Lou Gerstner was hired as IBM's chairman and CEO in 1993, his “first task was to change the ingrained attitudes that had prevented IBM from seeing the world around it” [15, pg 4]. Even with IBM on the brink of disaster, Gerstner found the "entire company was dangerously preoccupied with itself rather than customers" [4, pg 1] not unlike many university settings.
"In order to change the way it does things both successfully and radically, the institution must give up a preconceived notion of how it maintains itself and how it reacts to the external drivers in the marketplace" [7, pg 43]. The IBM board realized that a major change had to be made to save IBM; they hired Lou Gerstner, whose transformation of IBM is legendary. While the turnaround of the MIS program at a Midwestern university is not legendary, the faculty realized that a major change had to be made to address the downward spiraling enrollment. Faculty papers and presentations have previously discussed the process of curriculum redesign. This paper focuses on how we have used marketing techniques to attract and retain students to the MIS major.

\section{LITERATURE REVIEW}

Gerstner (2002) identified common components in successful companies, including outstanding customer service, excellence and teamwork. But these values are affected by how employees are motivated, work, and interact with one another. [6, pg 182] The guiding principle behind our efforts was recognizing that everything we needed to affect change existed within the four walls of the department. Marketing plans "work best when they are executed consistently as part of an overall plan of action that is intended to last from several months to a year" [5, pg 1]. One of the most difficult concepts to get across is that no matter how well the marketing campaign is designed, "if your staff isn't on board, if your employees aren't engaged and enthusiastic, the results will be unsatisfying." [5, pg 17] "In the end, an organization is nothing more than the collective capacity of its people to create value" [6, pg 182]. Fortunately, the faculty and staff are supportive of the changes being made and have "bought in" to the curriculum reengineering process and marketing strategy.

Feltenstein outlines "seven steps to creating a killer marketing plan:"

1. Gather data.

2. Analyze them.

3. Set goals.

4. Develop strategy.

5. Implement the plan.

6. Track the progress. 


\section{Evaluate the results [5, pg 43].}

In designing a marketing plan to recruit students into the major, the first step is gathering data about the core attributes that students use to make decisions in choosing a major [7, pg 104] and the knowledge that students have about careers in information systems.

According to a study conducted at Illinois State University, freshmen students have very little knowledge about careers in information systems [2, pg 228]. This study concludes that while traditional college age students "are members of a generation known for its pervasive use of technology, computers and computer-enabled devices, it appears they have little awareness of, or interest in, the occupations that are driving the digital age” [2, pg 230].

Simons et al. report the results of eight different studies examining the important factors influencing a student's choice of accounting as a major. Principle factors include earnings, career opportunities, career characteristics and characteristics of the major [11]. The top five factors reported in the Crampton et al. study of "Why" students selected a particular major included: personal interest in subject, long-term salary prospects, probability of working in the field after graduation, starting salary and prestige of profession [2].

Tillbury and Cohoon (2005) reported the most consistent themes that attracted students to the computer science major were "early experiences with computers, the match between a student's selfassessed abilities and the abilities required by computer science and the features of computing careers" [ 13, pg 126]. Other reasons for choosing a computer science major were career advancement, potential earnings, flexibility, interacting with people and usefulness to others [13]. Students who had a positive experience in required computing class were attracted to the major [13]. Cohoon (2002) emphasizes that faculty who enjoy teaching should be employed in beginning classes. Students can be retained when they "encounter their department's most accessible, motivated teachers" [13, pg 51]. In fact, personal encouragement from professors may have a larger impact on females than on males, which could assist in recruiting females. [13]

After analyzing information regarding factors that influence student decisions about majors, it is time to develop a strategy using proven marketing and promotional techniques.
"It is a basic principle of promotional tactics that motivated, smiling employees attract loyal customers" [5, pg 17] and that "good customer service executed with a smile is the single most important reason that customers patronize one business rather than another" [5, pg 17]. Using these basic tenets, a customer advantage approach formed the basis of the marketing and promotion strategy.

A customer advantage philosophy is a way of "engaging in a market to seek excellence in the offering to the customer and to allow customers to determine who should flourish" [7, pg 41]. In the customer advantage marketing approach core competencies, partnerships, and relationships dominate. The goal is to exceed customer expectations and build customer loyalty. In the Internet Age, a customer-centric approach is important to any business [12]. Three common themes used to build customer loyalty are: "communicate with customers regularly, be enthusiastic and create fun and excitement” [12, pg 28].

For a business catering to college students, Feltenstein identifies the following as important objectives: increase awareness, increase community goodwill, increase frequency, generate traffic, and stimulating trial [5]. While all of these objectives and associated tactics do not fit directly into promoting a major, many can be appropriately adapted. Awareness is the "first step to bringing in new customers" [5, pg 3]. The student must know of the major's existence and what makes MIS different from other majors. Community goodwill is the "creation of a positive image of your business or organization in your community. No matter how large or small your business or organization may be, you put out an image that reflects on you positively or negatively" [5, pg 3]. Frequency tactics are "geared toward establishing your business as the place to go in your category” [45, pg 3]. Generating traffic "promotions are designed to attract people into your operation" [5, pg 4]. Stimulating trial "promotions are designed to get people to try you out. Customers who already know about you may not have been motivated to try you. Promotions that are designed to stimulate trial offer something that is special enough to give potential customers the push they need.” [5, pg 5]

\section{PROCESS}

In developing a marketing strategy for the MIS program, our team focused on delivering a consistent message across the entire curriculum. The message 
delivery begins in the introductory information systems class offered to all incoming freshmen in the College of Business. Our marketing strategy is designed to provide students with information regarding the varied and exciting careers available to MIS majors while focusing on factors that students use to make decisions about majors. This beginning course explores web design, usability and the visual display of information. The guiding principles of the course are to make information display compelling, professional and visually appealing and to present the greatest amount of good information in the space available. This course, which is a core requirement, gets the students excited about the role of information systems in business decision making.

In a second core requirement, career information is presented using testimonials from alumni and presentations from upper-class students, as well as data from the bureau of employment statistics. "Sales experts long ago concluded that "word of mouth" and "personal testimonials" are the best types of advertising” [1, pg 33] and we have found the alumni and upper-class students to be effective spokespersons and recruiters.

Bureau of labor statistics information which shows predicted job growth is shown in Table 1 . The job growth predictions address the concerns that students may have regarding a future career in information systems [14]. This information can be used to contradict the fear of no information system jobs due to outsourcing.

Table 1. Projected job growth.

\begin{tabular}{|l|l|}
\hline Job Growth Through 2012 & Percent \\
\hline Programmers & 10 to $20 \%$ \\
\hline $\begin{array}{l}\text { Support Specialists, System } \\
\text { Administrators }\end{array}$ & 20 to $35 \%$ \\
\hline $\begin{array}{l}\text { Systems Analysts, Database } \\
\text { Administrators }\end{array}$ & Over 35\% \\
\hline
\end{tabular}

Starting salary information for undergraduate degrees in business fields is shown to confirm the salary a Bachelors degree candidate in MIS might receive. National starting salary data as reported by NACE [9] is shown in Graph 1.
Graph 1. National undergraduate starting salaries.

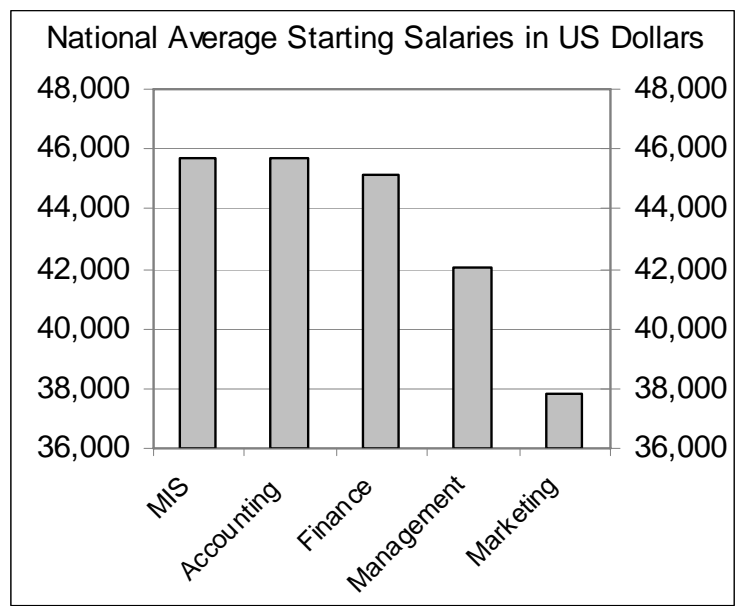

Starting salary data for Ohio University as compared to national averages for undergraduates is shown in Graph 2. The salary data for graduates shows the relationship between major and starting salary. The presentation of salary data opens the opportunity to suggest that a double major could enhance employment opportunities.

Graph 2. Undergraduate starting salaries for Ohio University compared to national averages.



The last part of our message includes presentations about the curriculum and the customer/student centered faculty and staff. By applying the principles of relationship marketing, each faculty and staff member within the department communicates a consistent message to students. In every interaction with students we emphasize that the MIS department is a customer centric, student focused department which provides students with the knowledge sought 
by employers for jobs related to the strategic application of information systems.

\section{THE RESULTS}

The marketing plan was implemented during the spring term of the 2004 - 2005 academic year. Enrollment in the first course for MIS majors has increased $141 \%$ since the low enrollment point in 2003. Both the headcount and the percent of enrollment demonstrate an increase in the number of double majors starting the MIS curriculum. The graphs below show how the enrollment has increased over the last two years and the changing composition of majors in the beginning course. Graph 3 demonstrates that the percent of total enrollment from double majors has increased and percent of total enrollment from MIS majors has decreased.

Graph 3. Percent of enrollment by major in beginning course by major.

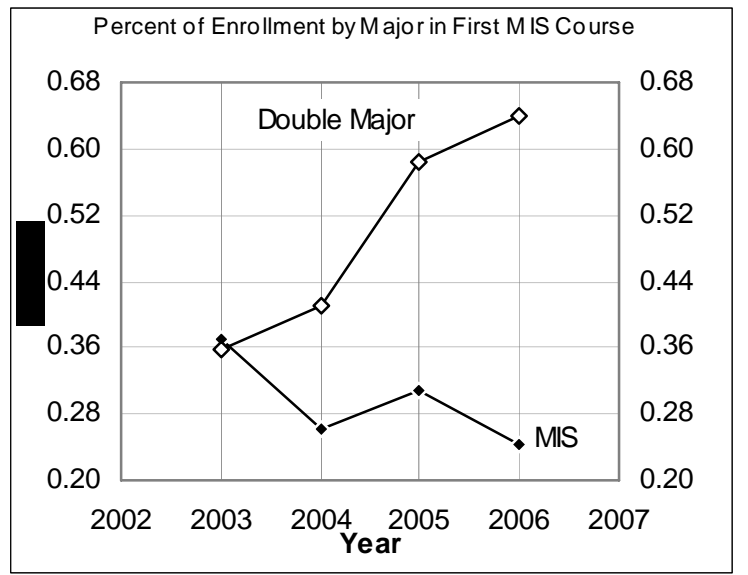

Graph 4 demonstrates the headcount enrollment by major. The headcount for MIS majors has increased, even though the percent of MIS majors enrolled as compared to other majors has decreased. The headcount for double majors has increased 328 percent.
Graph 4. Enrollment in beginning course by major.

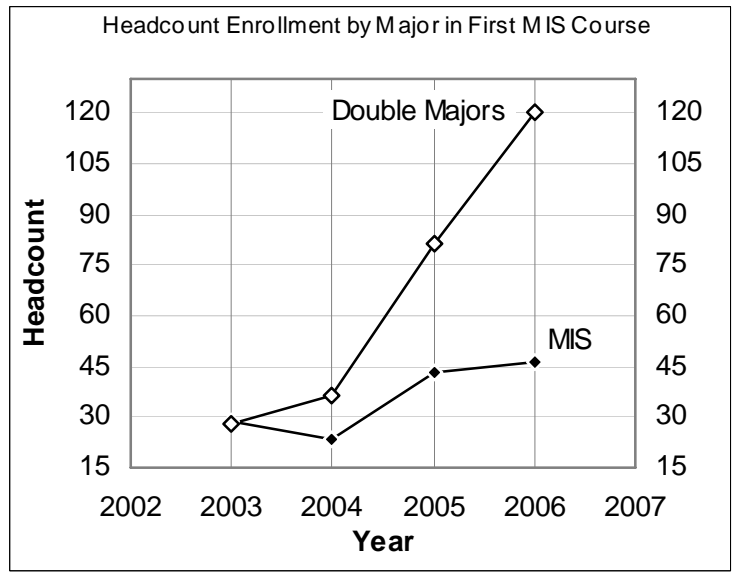

Headcounts for all business majors have increased. The enrollment for MIS majors has increased by $52 \%$, enrollment for Marketing majors has increased $417 \%$, the increase for Accounting majors is $500 \%$, for Finance majors $300 \%$ and the enrollment increase is over $100 \%$ for Management and General Business majors. Graph 5 shows the breakdown of the double majors enrolling in the first MIS course.

Graph 5. Headcount enrollment breakdown by major for beginning MIS course.

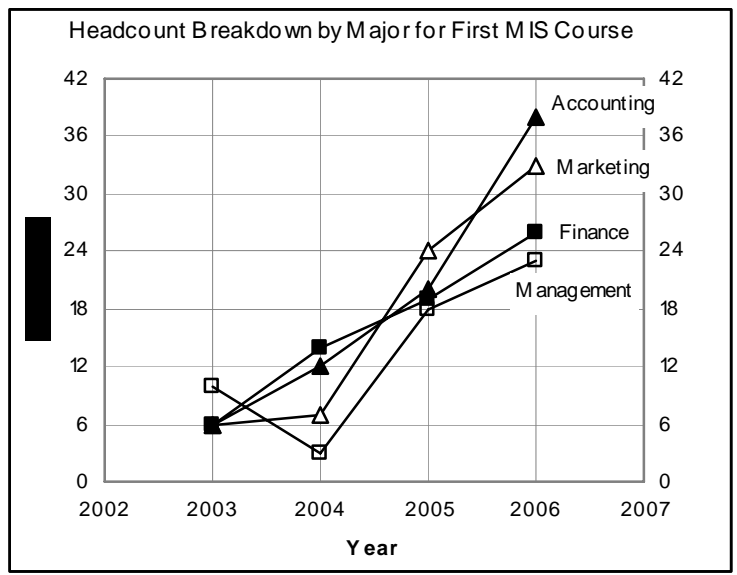

The increased enrollment from other business majors indicates that there are more double majors giving MIS a try. This increase in double majors is consistent with our marketing strategy to get students to try the MIS program.

Graph 6 shows the total enrollment for all students in the first course in the MIS curriculum. As stated earlier, enrollment increased 141\% from 2003 through 2006. 
Graph 6. Headcount enrollment in beginning MIS course.

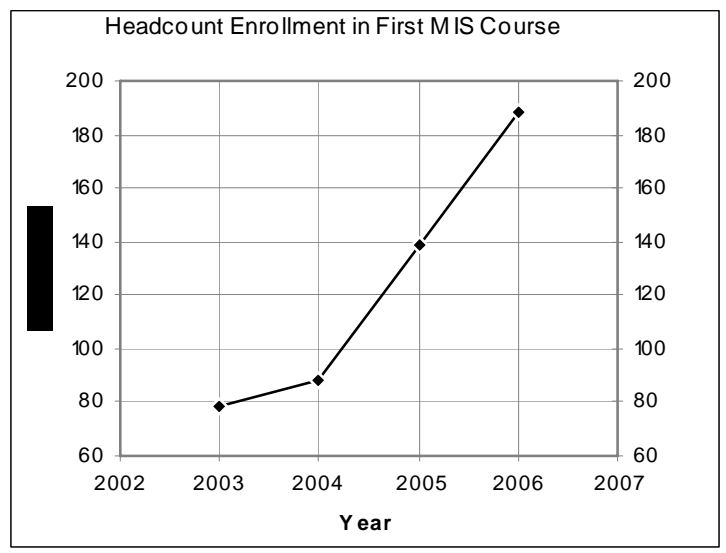

The increased enrollment in the beginning course indicates that students are willing to try MIS. Even though there is a lag as students move through the major, enrollment numbers in the database course, the next course in the curriculum, and the capstone course indicate retention in the major. Graph 7 shows the total enrollment for the database course, and the capstone course. Enrollment in the database course increased 135\% since the low point in 2004 . Enrollment in the capstone class has not yet reached the levels of 2003, but this is to be expected since there could be as much as a two year lag as students enter the curriculum and progress to the capstone course. Enrollment in the capstone class increased 112\% from the low point in 2005.

Graph 7. Headcount enrollment in database and capstone courses



Increased enrollments were a positive sign that our message was working, but after two years, it was time to ask the students for feedback. Using the single question technique described by Reichheld [10], sixty students in the beginning programming course were asked to anonymously answer this question; "Would you recommend MIS to your friends?" Fifty Eight students answered the question and fifty-four of those students said, yes, they would recommend MIS to a friend. In addition to surveying students in the beginning course, anecdotal data is collected from students in the capstone course during exit interviews. These senior students report that the MIS department is the most student focused and has the most accessible faculty that they have encountered during their undergraduate career. The result of the simple question and the exit interviews confirm that our marketing campaign is working. With students acting as marketers and spreading our message to their friends we should continue to see robust enrollment in MIS courses.

\section{CONCLUSION}

Just as in business downturns, drastic actions are needed to turn around the death spiral of MIS enrollment. We have implemented an integrated strategy of curriculum reengineering and marketing practices to get our message out to the student community. Faculty are united and committed to delivering a clear and consistent message across the curriculum, beginning with the introductory class through the capstone course. The approach has produced increased enrollment and student satisfaction with the curriculum and learning environment. Any MIS department willing to accept that the solution to decreasing enrollment rests within the department can replicate our efforts and potentially increase the number of majors.

\section{REFERENCES}

1. Albrecht, W. S. \& Sack, R. J. (2000). Accounting education: charting the course through a perilous future, Accounting Education Series, 16, Sarasota, FL: American Accounting Association.

2. Crampton, W. J., Walstrom, K. A., \& Schambach, T. P. (2006). Factors influencing major selection by College of Business students, Issues in Information Systems, VII,(1), 226-230.

3. Cohoon, J. McGrath. (2002). Recruiting and retaining women in undergraduate computing majors, SIGCSE Bulletin, V34,(2), 48-52.

4. Dicarlo, L. (2002). How Lou Gerstner got IBM to dance. Forbes.Com available online at http://www.forbes.com/2002/11/11/cx_1d_1112 gerstner_print.html. 
5. FeltenStein, T. (2005). 401 killer marketing tactics to increase sales and stomp your competition. New York, NY: McGraw-Hill.

6. Gerstner, L. V. (2002). Who says elephants can't dance: Inside IBM's historic turnaround. New York, NY: HarperCollins.

7. Gibbs, P. \& Knapp, M. (2002). Marketing higher and further education: An educator's guide to promoting courses, departments and institutions. Sterling, VA: Stylus Publishing, Inc.

8. Ohio Board of Regents, HEI Reports web site. http://qry.regents.state.oh.us/cgipub/site_map?name=bds_sid\&jsflag=yes

9. National Association of Colleges and Employers, NaceWeb available online at http://www.naceweb.org/

10. Reichheld, F. F. (2003). The one number you need to grow. Harvard Business Review, 47 -54.

11. Simons, K.A., Lowe, D.R. \& Stout, D. E. (2003). Comprehensive literature review: factors influencing choice of accounting as a major. Proceedings of the 2003 Academy of Business Education Conference.

12. Sindell, K. (2000). Loyalty Marketing for the Internet Age. Chicago, IL: Dearborn Financial Publishing.

13. Tillberg, H. K. \& Cohoon, J. M. (2005). Attracting women to the CS major. Frontiers, V26, (1), $126-140$.

14. U. S. Department of Labor, Bureau of Labor Statistics available online at http://www.bls.gov/oco/oco2003.htm

15. Worth, R. (1999). What Lou Gerstner could teach Bill Clinton: Lessons for government from IBM's dramatic turnaround. The Washington Monthly Online 31(8) available online

http://www.washingtonmonthly.com/features/1 999/9909.worth.ibm.html. 